\title{
微粒子励振型流量制御弁におけるねじり振動を利用した 駆動原理の有効性評価*
}

\author{
廣 岡大 祐 ${ }^{* *}$, 東 一 毅***, 古城 直 道**, 山口 智 実**
Effectiveness of Driving Method using Torsional Vibration for Particle- Excitation Flow Control Valve

\author{
Daisuke HIROOKA, Kazuki AZUMA, Naomichi FURUSHIRO, Tomomi YAMAGUCHI
}

\begin{abstract}
This paper reports a novel driving method for particle-excitation flow control valve. The valve that we have designed in previous reports can control air flow continuously with small size and light weight. Because the valve conditions air flow, using particle excitation by piezo vibration, the valve has potential for high response. However, in previous model, the vibration direction is opposite to air flow direction and a large scale vibration is necessary to open the valve. In this report, to decrease necessary vibration scale, we design novel driving mechanism using torsional vibration. The method generates vibration that is perpendicular to air flow by torsional vibration. First, we explain the designed mechanism and calculate the vibration scale to open the valve. And we design a prototype that can generate torsional vibration to check the mechanism. Additionally, we measure the vibration scale at valve opening condition in experiment and compare calculated and experimental results. Through this study, we show the advantage of the mechanism.
\end{abstract}

Key words : Particle excitation, Piezoelectric Element, Pneumatic, Actuator, Flow control

\section{1. 緒言}

空気圧アクチュエータはコンプライアンス性を有し, 安 全性も高く, リハビリテーション機器やパワーアシスト装 置への応用の研究が行われている ${ }^{1-3)}$. また, 軽量で大きな 力を出すことが可能な, 空気圧人工筋などのソフトアクチュ エータの研究も進められている ${ }^{4-9)}$. これらのアクチュエー 夕の制御機器は, 大きく $\mathrm{ON}-\mathrm{OFF}$ 弁とサーボ弁に分けられ る. $\mathrm{ON}-\mathrm{OFF}$ 弁は比較的小型軽量で応答性が高いという特 徵があるが連続的な流量制御にはサーボ弁が必要となる. 一般的なサーボ弁はON-OFF弁と比較し, 大型で応答性も 低い. 著者らは, 小型のサーボ弁への応用を目指し, 微粒 子を弁体として使用し, 連続的な流量調整が可能な微粒子 励振型流量制御弁を開発している ${ }^{10-14)}$ 。 この制御弁はオリ フィス板を圧電素子で励振させることで, 弁体として働く 微粒子を動かし, 弁開度を変化させる構造となっている. この構造では, 複数のオリフィスと微粒子を用いることで 連続的な流量制御が可能となる. また, 空気による圧力で

\footnotetext{
*平成30年 2 月 25 日 原稿受付

$* *$ 関西大学

(所在地 : 大阪府吹田市山手町 3-3-35)

(E-mail : hirooka@kansai-u.ac.jp)

***関西大学大学院

(所在地：大阪府吹田市山手町 3-3-35)
}

微粒子をオリフィスに押し付けているため, 弁体を固定す る機構が不要で, 小型で大流量の連続的な制御が可能とな る ${ }^{11)}$.さらに弁体の駆動に圧電素子を用いることで高い応 答性も期待できる ${ }^{12)}$. 過去の研究では, 手動の絞り弁と同 等の質量の試作機で空気圧シリンダの速度を切り替えるこ とが出来た ${ }^{13)}$. また, $\mathrm{ON}-\mathrm{OFF}$ 弁と同等の質量の試作機で オリフィスの配置条件を最適化することで印加電圧に比例 した出力流量を得ることに成功した ${ }^{14)}$. この制御弁の特徴 に着目した小型の油圧制御弁の研究も行われている ${ }^{15)}$. 一 方, 過去の研究で提案した駆動原理では, オリフィス板の 振動の方向と空気による圧力の方向が対向しており微粒子 の駆動に大きな力が必要であった。この駆動原理の改善方 法として空気圧と直交する方向の力を利用する方法が考え られる. 現在までに, 空気圧や油圧において省電力化を目 的として弁体を開く際に流体による圧力に直交する方向の 外力を与える弁の研究が行われている ${ }^{16-19)}$. 本研究では, 微 粒子の駆動に必要な力の低減を目指して, 圧電素子による ねじり振動を利用し, 空気圧に直交する力を加える駆動原 理を提案した. ねじり振動が発生可能な試作機を作製し実 験を行うことで提案した駆動原理の有効性の評価を行った。

本論文では，まずねじり振動により空気圧に直交する振 動を与える駆動原理を説明する. 次に, 提案した駆動原理 において, 空気圧と直交する方向の振動と空気圧に対向す る方向の振動を組み合わせた際の微粒子の駆動に必要な条 件を理論的に求める. 理論值より, 空気圧に直交する振動 
を利用することで微粒子の駆動に必要な力の低減が可能で あることを確認する，さらに，空気圧と直交する方向の振 動としてねじり振動を発生可能な試作機の設計について示 す. 次に作製した試作機の振動特性を実験により確認する。 そして, 確認した振動特性より, 実験条件を決定し，微粒 子の駆動に必要な条件を実験的に求め, 理論值との比較を 行う。理論值と実験結果の比較から，提案する駆動原理が， 微粒子の駆動に必要な力の低減において有効であることを 示す.

\section{2. 主な記号}

$\begin{array}{ll}R & : \text { オリフィス半径 } \\ r & : \text { 微粒子半径 } \\ m & : \text { 微粒子質量 } \\ P & : \text { 空気圧 } \\ F & : \text { 慣性力 } \\ \theta & : \text { 空気圧による押し付け力と慣性力がなす角 } \\ \phi & : \text { 微粒子とオリフィスの接触角 } \\ a & : \text { 振動加速度 } \\ d & : \text { オリフィス板中心からの距離 } \\ \text { 添字 } & \\ f & : \text { 曲げ振動 } \\ t & : \text { ねじり振動 }\end{array}$

$\mathrm{mm}$

$\mathrm{mm}$

$\mathrm{kg}$

$\mathrm{MPa}$

$\mathrm{N}$

deg

deg

$\mathrm{m} / \mathrm{s}^{2}$

$\mathrm{mm}$

\section{3. ねじり振動を利用した駆動原理}

\section{1 微粒子励振型流量制御弁の概要 ${ }^{10)}$}

過去の研究で提案した微粒子励振型制御弁の駆動原理を Fig. 1に示す.この流量制御弁はオリフィス板, 微粒子, 圧電素子から構成されている.オリフィス板には複数のオ リフイスが設置されており，管路内部に空気が供給される と, Fig. 1(a)のように，微粒子がオリフィス開口部に空気 圧により押し付けられ弁が閉じた状態となる。弁が閉じて いる状態で, Fig. 1(b)のように, 圧電素子により, オリフィ ス板を振動させ，微粒子に振動による慣性力を与えること で，オリフィスが開き流量が変化する。この制御弁では, 開口するオリフィス数を変化させることで連続的な流量変 化が可能である．また，振動条件とオリフィス配置を最適 化することで，圧電素子に印加する電圧に対して比例する 流量を出力することも可能である ${ }^{14)}$. 一方で過去の試作機

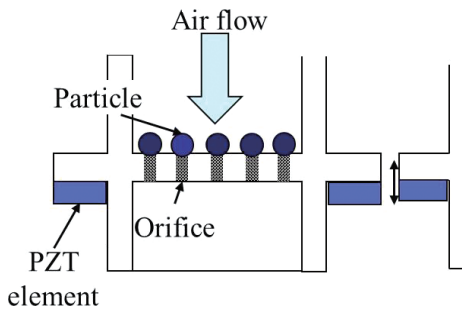

(a)

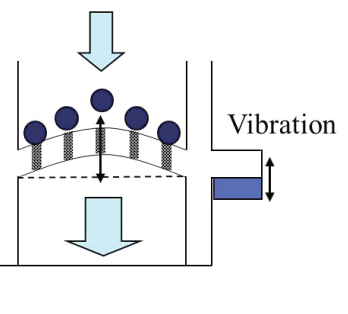

(b)
Fig.1 Schematic of particle-excitation variable
では，Fig. 1(b)のようなオリフィス板が空気圧に対向する 向きに振動する条件を用いていた，この条件では，微粒子 を動かすには空気圧による押し付け力より大きな力が必要 であった，本研究ではオリフィス板に圧電素子によるねじ り振動を発生させ，微粒子に空気圧による押し付け力と直 交する方向の振動を加えることで，微粒子の駆動に必要な 力の低減を目指す。

\section{2 ねじり振動による駆動}

Fig. 2にねじり振動の概要を示す．Fig. 2(a)は振動子に発 生するねじり振動の概略である，振動子にねじり振動が発 生した場合, Fig. 2(a)に示すように振動子全体で円周方向 の振動が起こる. ねじり振動では振動子の端が振動の腹と なり，振動子の端にオリフィス板を設置すると，オリフィ ス板には円周方向の振動が発生する。 その結果, オリフィ ス上の微粒子には円周方向の慣性力がかかる. Fig. 2(b)は ねじり振動が発生しているオリフィス板の概要である. Fig. 2(b)に示すように, ねじり振動が発生し, オリフィス 板が微小角回転すると, オリフィス板上では中心からの距 離に比例した変位が発生する。 このため, 各オリフィスで 発生する慣性力はオリフィス板の中心からの距離に比例し， オリフィスの配置位置により開口条件を変化させることが でき，連続的な流量調整が可能となる．また，この振動で は，オリフィス板の外側ほど振動による慣性力が大きくな る. そのため, 慣性力の大きな箇所に, 複数のオリフィス を設置することができ，効率的な駆動が可能となる，一方 で, オリフィス板の共振周波数ではFig. 1(b)に示すように, オリフィス板が大きく変形する曲げ振動が発生する.今回 の条件ではオリフィス板で発生する曲げ振動は空気圧と対 向する向きとなる，ねじり振動と曲げ振動を組み合わせる ことで, 空気圧に直交する力と, 空気圧に対向する力を同 時に発生することが出来る. 本論文では, これらの力の比 率を変化させた際の微粒子の運動に必要な条件を確認する。

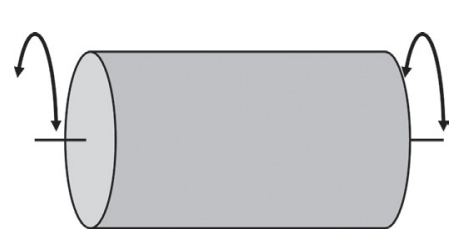

(a)

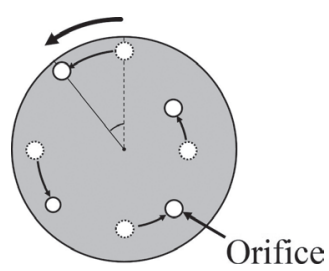

(b)
Fig. 2 Schematic of torsional vibration

提案する駆動原理におけるオリフィス上の微粒子にかか る力のつり合いをFig. 3に示す．本研究におけるねじり振 動と曲げ振動のように, 空気圧に対して垂直な方向の力と 対向する方向の力が混ざった状態で, 微粒子が運動しオリ フィスが開口するための条件は, Fig. 3に示すように, オ リフィスの縁である点Oに対するモーメントのつり合いで 考えられる。 


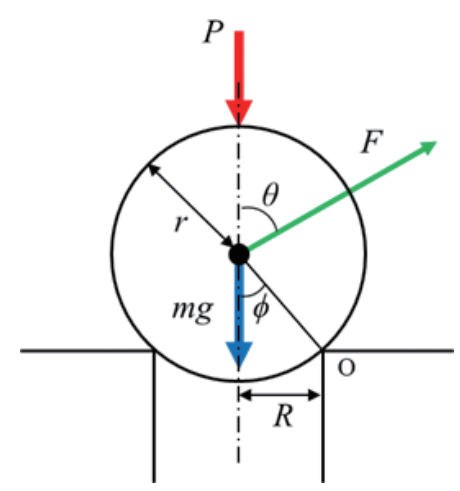

Fig. 3 Force balance of particle on the orifice

オリフィス半径を $R$, 微粒子の半径を $r$, 質量を $m$, 空気 圧 $P$ とし, 点O周りのモーメントを考えると, 空気圧によ り発生するモーメント $N_{l}$ は以下のようになる.

$$
N_{1}=\left(\pi R^{2} P+m g\right) R
$$

ここで微粒子の中心に振動による慣性力が空気圧となす 角 $\theta$ で働く場合, 慣性力 $F$ にり微粒子に働く点O周りの モーメントを求めると以下のようになる.

$$
N_{2}=F R \cos \theta+F r \cos \phi \sin \theta
$$

なお, 角度 フィス半径 $R$ と微粒子半径 $r$ よって決まり以下の式で表せる.

$$
\phi=\arctan \left(\frac{R}{\sqrt{r^{2}-R^{2}}}\right)
$$

オリフィスが開口するためには, $N_{2}>N_{1}$ となる必要があ る. よって, 開口条件となる際の慣性力は以下の式のよう になる

$$
F>\frac{\left(\pi R^{2} P+m g\right) R}{R \cos \theta+r \cos \phi \sin \theta}
$$

ここで $\theta=0$ の場合, 式(4)の右辺は最大となるので開口 に必要な慣性力の最大值 $F_{\text {max }}$ は以下のようになる.

$$
F_{\text {max }}=\pi R^{2} P+m g
$$

式(5)より空気圧に対向する力で微粒子を動かそうとする と, 空気圧による押し付け力より大きな力が必要なことが 確認出来る. よって空気圧と直交する力が加わった， $\theta>$ 0の条件では, オリフィスの開口に必要な力を低減できる ことがわかる. 空気圧と直交する力が加わった状態で, 式 (4)で求められた条件より大きな慣性力が微粒子に与えられ ると, 微粒子はオリフィスの縁を基準に回転することで, オリフィス開口量が増加する。

次に, 微粒子の駆動に必要な力の低減の比率について述 べる. 微粒子の質量が相対的に小さく $m g$ が無視できる場合, 式(4)は以下のように変形できる.

$$
F>\frac{\pi R^{3} P}{\sqrt{R^{2}-r^{2} \cos ^{2} \phi} \sin (\theta+\alpha)}
$$

ここでFig. 3より $r \cos \phi$ は以下のように表すことが出来る ので,

$$
r \cos \phi=\sqrt{r^{2}-R^{2}}
$$

式(7)を式(6)に代入すると微粒子の駆動に必要な慣性力の
最小值 $F_{\min }$ は以下のようになる.

$$
F_{\min }=\frac{\pi R^{3} P}{r}
$$

よって微粒子質量が小さく重力による影響が無視できる 条件では, 式(5)と式(8)より慣性力の最大值と最小值の関係 は以下のようになる.

$$
\frac{F_{\min }}{F_{\max }}=\frac{R}{r}
$$

上記の結果より空気圧と垂直な方向の力を加えることで, 微粒子の駆動に必要な慣性力を低減させることが可能であ り, 低減できる比率はオリフィス半径に対する微粒子半径 で決まることが明らかになった，微粒子半径を拡大するこ とで, 大きな低減効果を得ることが可能となるが, 微粒子 とオリフィスとの接触面積が相対的に減少し, 不安定にな るため, 微粒子径の拡大には限界があると考えられる.

次に, 慣性力の向きと微粒子の駆動に必要な力の大きさ の関係を求める. 本報では, 空気圧と直交する力を用いた 際の有効性を明らかにすることを目的とし, 微粒子の駆動 に必要な慣性力を最大值の 3 分の 1 に低減できる条件とし てオリフィス半径を $0.2 \mathrm{~mm}$, 微粒子半径を $0.6 \mathrm{~mm}$ とした. 微粒 子の材質をSUS304 (密度7.93 $\left.\times 10^{3} \mathrm{~kg} / \mathrm{m}^{3}\right)$ とすると, 微粒 子半径 $0.6 \mathrm{~mm}$ の際の質量は $7.17 \mathrm{mg}$ となる. 空気圧 $0.6 \mathrm{MPa}$ 印加 時の空気圧による押し付け力は $75 \mathrm{mN}$ 程度となるため, 重 力による影響は無視できる. 上記の条件において式(4)より $\theta$ と慣性力の関係はFig. 4のようになる. Fig. 4より $\theta$ が大き くなり, 力が働く向きが空気圧と垂直方向に近づくと微粒 子の駆動に必要な慣性力が小さくなることが確認できる. 今回の条件では $70^{\circ}$ 付近で必要な慣性力が最小となり最大 時の 3 分の 1 程度となっていることが確認出来る.

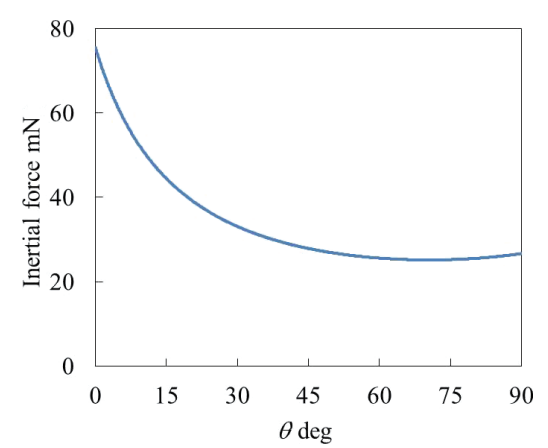

Fig. 4 Relationship between force angle and necessary force

次に, 慣性力をねじり振動加速度と曲げ振動加速度に置 き換える，微粒子が駆動する前であれば，微粒子の振動加 速度はオリフィスの縁で発生する振動加速度に等しい. ね じり振動加速度 $a_{t}$ と, 曲げ振動加速度 $a_{f}$ は, 慣性力 $F$ 用い てそれぞれ以下のように表せる。

$$
a_{t}=\frac{F \sin \theta}{m}
$$




$$
a_{f}=\frac{F \cos \theta}{m}
$$

式(4)，式(10)，式(11)を用いてFig. 4の值を $a_{t}$ と $a_{f}$ の関係に書き 換えるとFig. 5のようになる. Fig. 5より曲げ振動のみで微粒 子を動かす場合, 必要となる振動加速度は約 $10.5 \mathrm{~km} / \mathrm{s}^{2}$, ね じり振動のみで運動させる場合, 必要となる振動加速度は $3.7 \mathrm{~km} / \mathrm{s}^{2}$ となることが示される。 これらの結果より，ねじり 振動により微粒子に空気圧と直交する慣性力を与えること で，微粒子の駆動に必要な力の低減が可能であると考える.

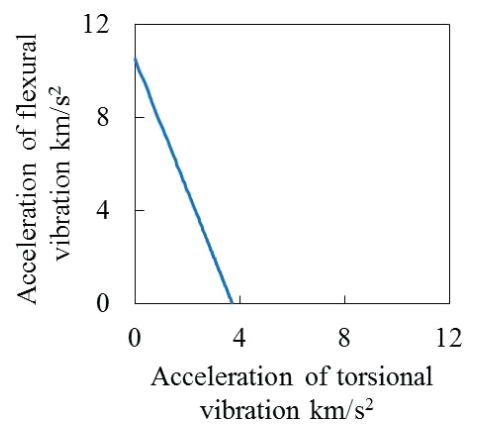

Fig. 5 Ratio of torsional vibration and flexural vibration at driving condition

\section{4. 試作機の作製}

\section{1 試作機構造}

本研究で作製する試作機では，振動子全体でねじり振動 を，オリフィス板部分で曲げ振動を発生させ，空気圧と直 交する力と対向する力を発生させる. 周波数やオリフィス 配置位置により振動の比率を変化させ，前章で求めた理論 值との比較を行う。ねじり振動が発生可能な試作機として ボルト締めランジュバン型振動子を用いた. Fig. 6に作製 した試作機の断面図と圧電素子の概要を示す。試作機の構 成要素はオリフィス板部分, メインボディ, 圧電素子, 電 極, 圧電固定用ボルト, ナット, 空気圧継手からなる. Fig. 6(a)に示すように振動子内部は空洞になっており，固 定用のフランジ部分がある. また，フランジ部分の内部に 空気圧配管取り付け用の継手を固定している。発生するね じり振動は振動子先端で振動の腹に, フランジ部分と圧電 素子の部分では振動の節となるよう設計されている. 試作 機の直径 $40 \mathrm{~mm}$, 長さ $80 \mathrm{~mm}$ であり, オリフィス板は直径 $30 \mathrm{~mm}$, 厚さ $1.2 \mathrm{~mm}$ である，振動子に用いる圧電素子の分極方向を Fig. 6(b)に示す. 図中の矢印は圧電素子の分極方向である. 圧電素子全体の分極方向が円周方向となるように，8分割 して分極処理を行い，接着しリング状とした．このため圧 電素子は電圧印加時に円周方向の変位を発生する. 振動子 には 2 枚の圧電素子の分極方向が対向するように配置され ており，振動子全体でねじり振動が発生する構造となる。 有限要素法解析により求めた試作機のねじり振動をFig. 7 に示す. Fig. 7より試作機全体でねじり振動が発生し，才
リフィス板の部分が振動の腹に, フランジ部分が振動の節 になっていることが確認出来る.

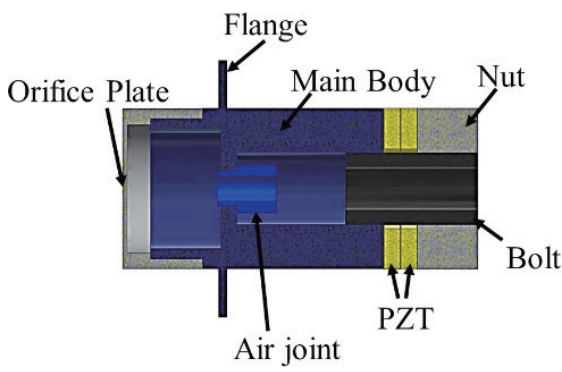

(a) Cross section of the prototype

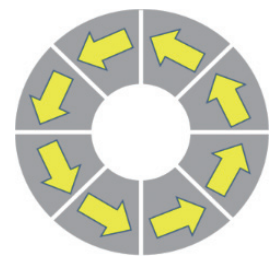

(b) Polarization direction of PZT element

Fig. 6 Schematic of prototype

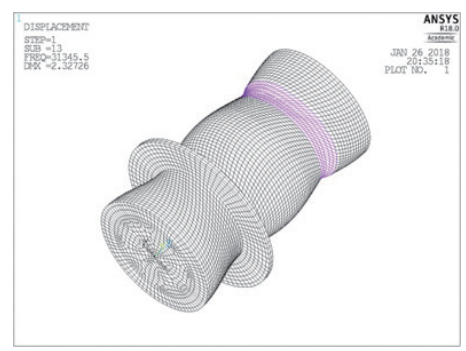

Fig. 7 Vibration mode of torsional

次にこの試作機のオリフィス板に発生する曲げ振動を求 め, ねじり振動と変位の分布を有限要素法解析で比較した 今回必要とされる振動条件は, ねじり振動と近い周波数で 発生し，オリフィス板部分で大きな振動加速度が発生する 振動モードである. Fig. 8に作製した試作機で発生する振 動モードの変位の分布を示す. 図中で赤色の箇所は変位の 比率が高く，青色の箇所での変位の比率が低い. Fig. 8(a) はねじり振動のモデルである。ねじり振動では，オリフィ ス板の外側ほど変位が大きいことが確認出来る. 有限要素 法解析で求められた共振周波数は $31 \mathrm{kHz}$ であった．Fig. 8(b) およびFig. 8(c)はねじり振動が発生する周波数付近に存在 するオリフィス板に曲げ振動を発生させるモードである. Fig. 8(b)ではオリフィス板上に 2 つの振動の腹が, Fig. 8(c) では 4 つの振動の腹が確認される。 これらのモードの共振 周波数はそれぞれ $25 \mathrm{kHz}, 40 \mathrm{kHz}$ であった。曲げ振動のモー ドでは，オリフィス板中心と端が振動の節となり，その中 心に振動の腹となる部分が存在する。この結果より, オリ フィス板の外側ではねじり振動が，内側では曲げ振動が発 生しやすいことが確認された，以上の結果より，周波数と 
オリフィス位置を変化させることで, オリフィス上でのね じり振動, 曲げ振動の比率を変化させることが可能である ことが確認された. これらのモードを組み合わせ，空気圧 と垂直な方向の振動を用いる有効性を示す.

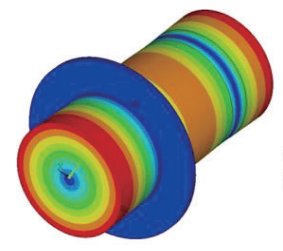

(a)

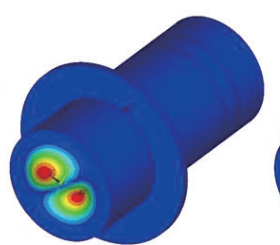

(b)

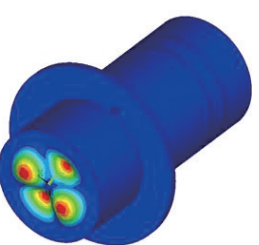

(c)
Fig. 8 Vibration modes of the prototype

実際に作製した試作機の外観をFig. 9に示す.Fig. 9(a)は 組み立てた試作機である。試作機はステンレスで出来てお り，圧電素子との間には電極として銅板が挿入されている. フランジ部分内部にある継手に, 空気圧配管を取り付け, 空気流路を形成している. Fig. 9(b)にオリフィス板の写真 を示す．オリフィス板部分は組立時に締め付けやすいよう に二面幅が $40 \mathrm{~mm}$ の正八角形とした.オリフィスは半径 $0.2 \mathrm{~mm}$ でテーパは設けていない.オリフィスごとの振動条件を変 化させるために，オリフィス板中心より $7.5 \mathrm{~mm}$ から $13 \mathrm{~mm}$ オで, 0.5mm間隔で12個のオリフィスを均等になるように配置した。

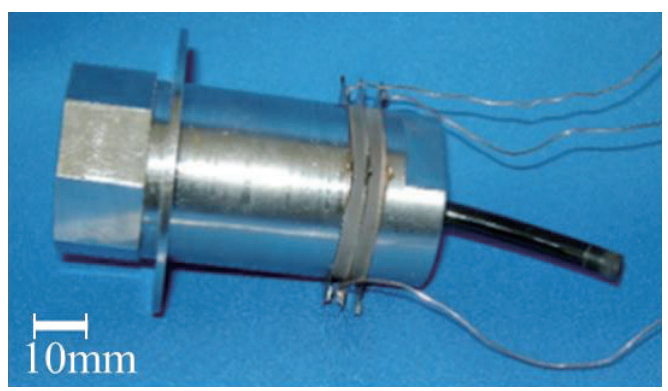

(a)

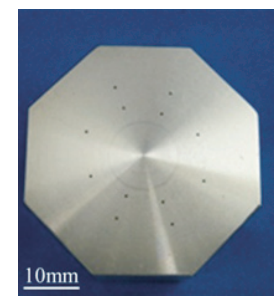

(b)

Fig. 9 Image of prototype

\section{2 試作機特性}

製作した振動子において発生する振動モードと周波数の 関係を, 振動加速度により示す。振動加速度はレーザー ドップラー振動計（Polytec NLV-2500）により測定した. 振動測定のモデル図をFig. 10に示す. Fig. 10に示すように ねじり振動はねじり振動が最大となるオリフィス板の角に
レーザーを照射し，曲げ振動はオリフィス板の所定の位置 にレーザーを照射することで測定した.

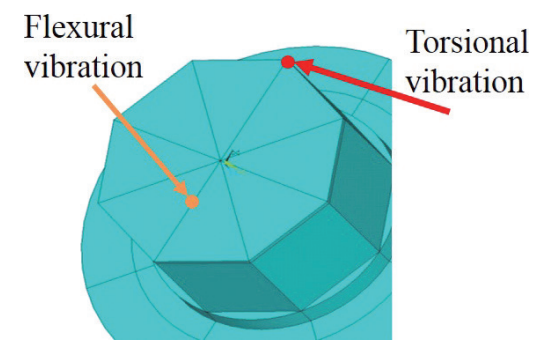

Fig. 10 Condition of measurement acceleration

Fig. 11に周波数と加速度の関係を示す. 印加電圧は100 $\mathrm{V}_{\mathrm{p}-\mathrm{p}}$ で, 曲げ振動は実験的に確認された振動の腹に近い中 心から $8 \mathrm{~mm}$ のオリフィス位置で測定した．Fig. 11において $27 \mathrm{kHz}$ 付近でねじり振動が大きく出ている箇所は, Fig. 8(a) に示すねじり振動のモードである. $28 \mathrm{kHz} よ よ ゙ 43 \mathrm{kHz}$ 付 近で曲げ振動が確認できる箇所が，オリフィス板に曲げ振 動が発生するFig. 8(b) とFig. 8(c)の振動モードである. Fig. 11より, ねじり振動が大きく発生する個所では, ねじ り振動と曲げ振動が混在した振動が，43kHzでは曲げ振動 を主体とした振動が発生することが確認できる.

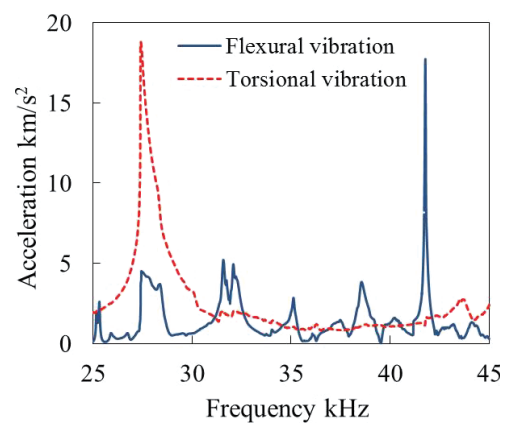

Fig. 11 Relationship between accelerations of the prototype and frequency

\section{5. 微粒子駆動条件の確認}

\section{1 実験条件}

本研究では, 振動子に印加する電圧の駆動周波数, オリ フィスの位置による振動条件の違いを利用し，ねじり振動 と曲げ振動の比率を変化させ微粒子の駆動に必要な条件を 明らかにする，そのためには指定のオリフィスにおける微 粒子の運動の有無, ねじり振動, 曲げ振動の大きさを確認 する必要がある. 本研究で用いる実験システムをFig. 12に 示す．指定のオリフィス上に微粒子を設置し, 駆動時のオ リフィス周辺で発生する振動加速度を測定することを目的 として専用の治具を作製しオリフィス板外側を空気室とし た．治具は試作機の振動特性に影響を与えないよう，振動 の節であるフランジ部分に固定した．治具の接触箇所では 
空気漏れがないよう○リングを設けた。オリフイス上の微 粒子の運動と振動加速度が測定できるように, 治具上面を アクリルで作製し中心に空気圧継手を設置した，微粒子の 運動の有無は流量計で微小流量の変化を測定することで確 認する．流量計は配管を介して試作機に取り付けられてい る. 治具内に供給された空気は試作機，流量計を通り大気 に解放される構造となっている.

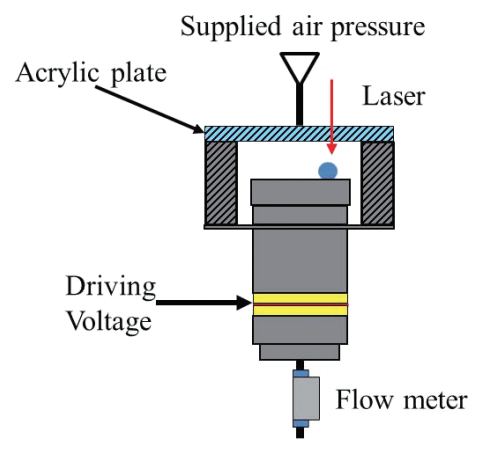

Fig. 12 Experimental setup

オリフィスで発生する曲げ振動は所定の位置をレーザー ドップラー振動計で測定することで，ねじり振動はオリ フィス板の角で測定した值から計算により求めた．ねじり 振動で発生する加速度は中心からの距離に比例するので, 端点で測定した振動加速度が $a_{\text {max }}$ のとき，オリフィス板中 心からオリフィスまでの距離をdとすると，以下の式でオ リフィス位置でのねじり振動を求めることが出来る.

$$
a_{t}=\frac{a_{\max } d}{d_{\max }}
$$

なお， $d_{\text {max }}$ はオリフィス板中心から，振動加速度を測定した オリフイス板の角までの距離である。微粒子が運動してい ない条件では, オリフィス部分で発生する振動加速度と, 微粒子にかかる振動加速度は等しい，よって，このシステ ムを用いることで所定のオリフィス上の微粒子の運動の有 無と, 微粒子にかかる振動加速度を算出することが出来る.

次に実験条件の選定を行う。理論值との比較のため，才 リフィスでの振動条件として, ねじり振動主体（条件 1), ねじり振動と曲げ振動の比率が 2：1 程度（条件 2), ね ビり振動と曲げ振動の比率が $1 ： 2$ 程度（条件 3 ）, 曲げ 振動主体の実験条件（条件 4）の 4 条件を選択した，条件 を満たすオリフィスと周波数を実験的に求めた．求められ た実験条件をTable 1に示す。選択した実験条件でのオリ フィスでのねじり振動と曲げ振動を測定し求めたりサー ジュ図形をFig. 13に示す. 周波数とオリフィスの位置によ り Fig. 13に示すようにねじり振動と曲げ振動の比率が変化 しており，それぞれの条件で目標とするねじり振動と曲げ 振動の比率が確認できた.

\section{2 微粒子駆動実験}

前節で求められた実験条件を用いて微粒子が駆動する際
Table 1 Experimental condition

\begin{tabular}{|l|c|c|}
\hline & Frequency kHz & $\begin{array}{l}\text { Distance from } \\
\text { center mm }\end{array}$ \\
\hline Condition 1 & 26.75 & 12.5 \\
\hline Condition 2 & 28.00 & 13.0 \\
\hline Condition 3 & 28.00 & 8.0 \\
\hline Condition 4 & 41.75 & 8.0 \\
\hline
\end{tabular}

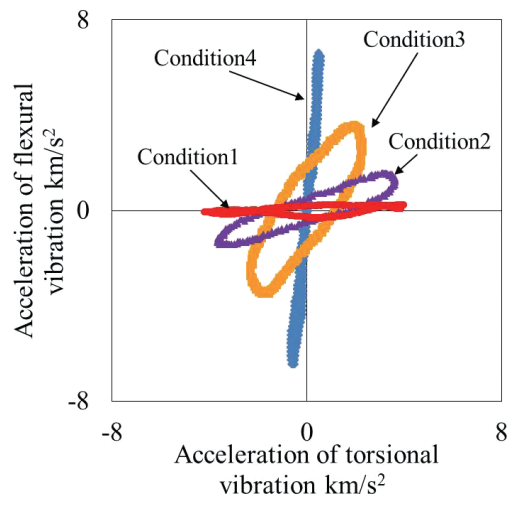

Fig. 13 Vibrational acceleration at experimental condition

の条件を測定する。求められた実験条件において印加電圧 により振動加速度を増加させ，流量の変化が確認された際 のねじり振動，曲げ振動の振動加速度を測定した．測定し た条件でねじり振動と曲げ振動のリサージュ曲線を描き, 振動加速度が最大となる点を求めた。一連の作業を各条件 で 5 回行い, Fig. 5の理論值と比較した. 実験にはFig. 12に 示したシステムを用い，微粒子を設置していないオリフィ スは空気漏れがないようテープで塞いだ。印加空気圧は $0.6 \mathrm{MPa}$ ，微粒子は半径 $0.6 \mathrm{~mm}$ の鋼球（SUS304）とした. 空 気圧測定には圧力計（KEYENCE AP-30A）を, 流量計は 分解能 $10 \mathrm{~mL} / \mathrm{min}$ 程度の微小流量計 (CKD FSM2-010) を用 いた．振動加速度の測定にはレーザードップラー振動計を 用いた. 駆動電圧の印加にはファンクションジェネレータ （NF回路 WF1948）と高速アンプ（NF回路 HSA4052）を 用い, 印加電圧の増加量は $1 \mathrm{~V}_{\mathrm{p}-\mathrm{p}}$ とした，実験の結果を Fig. 14に示す. Fig. 14より, 流量変化が確認された条件に おいて, 発生している振動加速度は理論值と近い值をとっ

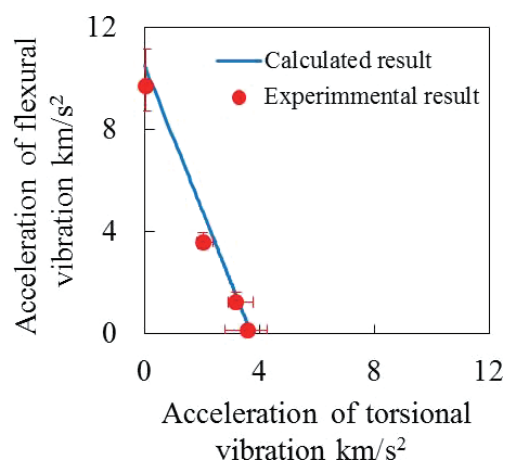

Fig. 14 Experimental results 
ていることが確認出来る. 実際に曲げ振動のみで流量変化 が確認された振動加速度とねじり振動が主体となる条件で 流量変化が確認された振動加速度を比較すると後者が前者 の 3 分の 1 程度となっている. 今回の各実験条件における 微粒子の質量は等しいため, 微粒子の駆動に必要な慣性力 は加速度によって決まる。この結果より空気圧と垂直な方 向の振動を用いることで, 微粒子の駆動に必要な慣性力の 低減が可能であることが示された。

次に流量変化が確認された条件での流量特性の一例を示 す. ねじり振動の比率が高かった条件 1 , 条件 2 での流量 をFig. 15(a)に，曲げ振動の比率が高かった条件 3, 条件 4 での流量をFig. 15(b)に示す. Fig. 15の0sが圧電素子に電圧 印加を開始した時間である. Fig. 15の各条件において電圧 印加以前にも空気の漏れが確認される. 漏れ量が一定でな い理由は, オリフィスごとの加工精度のばらつきによりオ リフィスと微粒子の接触条件が異なるためであると考えら れる. Fig. 15より, すべての条件において, 電圧印加後, すぐに流量が増加していることが確認出来る.この結果よ り圧電振動により慣性力を与えられたオリフィス上の微粒 子が運動することで流量が増加していると考えられる。ま た，すべての運動条件において，駆動後の流量特性が変化 している.この原因として微粒子の運動だけでなくオリ フィスの開口量の変化を考慮する必要がある．今回の駆動 条件において，与えられた慣性力は微粒子の駆動に必要な 力とほぼ等しいため, オリフィス開口量が小さい状態であ り，微粒子はオリフィス付近で運動していると考えられる.

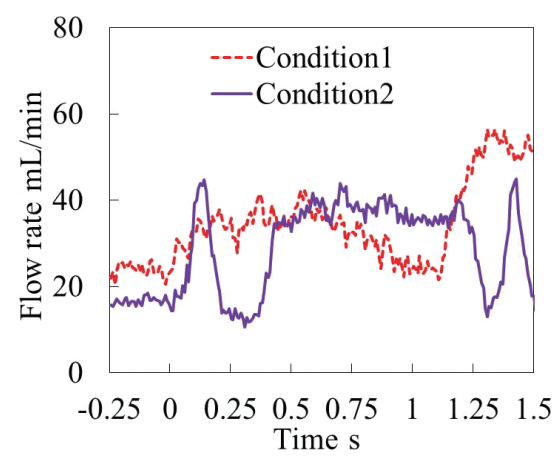

(a)

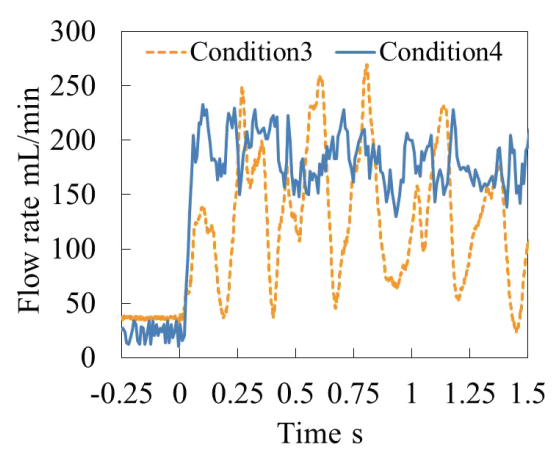

(b)

Fig. 15 Flow characteristics
この状態で, 振動により与えられる慣性力は周期的に変化 するので, 微粒子の運動状態も変化し, それに伴いオリ フィス開口量が変化していることが考えられる.

次に, 駆動原理による流量特性の違いを確認する. ねじ り振動の比率が高いFig. 15(a)は, 曲げ振動の比率が高い Fig. 15(b)と比べ発生している流量が非常に少ないことがわ かる.これは微粒子の運動状態の違いによるオリフィス開 口量の違いによるものと考えられる. 実験結果よりねじり 振動を用いた場合, 曲げ振動で駆動した場合と比較し, オ リフィス開口量が小さいことがわかる.この原因として微 粒子とオリフィスの縁でのすべりが考えられる. ねじり振 動が主体の条件において，オリフィスの開口量を増やすに は微粒子がオリフィスの縁に接触した状態で微粒子に慣性 力を与え, オリフィスの縁を中心に微粒子を回転させる必 要がある. その為, 微粒子とオリフィスの縁ですべりが起 こった場合, 微粒子がオリフィスから離れず, オリフィス 開口量は増加しない。一方，曲げ振動が含まれた条件では, オリフィスの縁と微粒子間ですべりが発生しても微粒子を オリフィスから離す方向の力が発生するので流量が増加し たと考えられる

\section{6. 結言}

本研究では微粒子励振型流量制御弁の駆動に必要な力の 低減を目的とし，ねじり振動を用いて空気圧に垂直な力を 発生させる駆動原理を提案し, その有効性を実験的に評価 した. まず, 静的な力の関係式より, オリフィス上の微粒 子に対して, 空気圧と垂直な方向の力を加えることで, 駆 動に必要な力を低減可能であることを確認した，次に，試 作機として, 空気圧と垂直なねじり振動と空気圧と対向す る曲げ振動を発生可能なランジュバン型振動子を作製し, ねじり振動，曲げ振動の発生を確認した。作製した試作機 において, 駆動する周波数, オリフィスの位置により発生 する振動の条件を変化させることで, 実験条件を変化させ, 理論值との比較を試みた。実験では, 流量の変化により微 粒子の運動の有無を確認し, 微粒子の運動が確認された際 の加速度を測定し, ねじり振動, 曲げ振動の振動加速度と 理論值を比較した。 その結果, 微粒子の運動が確認された 際の加速度は理論值と良く一致しており, ねじり振動によ り空気圧と垂直な力を与えることで, 微粒子の運動に必要 な加速度を低減できることが確認された。 また，微粒子の 運動が起こる条件を理論值により求めることが出来ると確 認されたので, 複数のオリフィスを開口条件に合わせて設 置することで, 連続的な流量制御が可能となると考えられ る. 一方で, ねじり振動主体の条件下で得られる流量は空 気圧に対向する曲げ振動の比率が多い条件で得られる流量 と比較して少なかった。これはねじり振動による駆動では オリフィスの縁ですべりが発生した場合オリフィス開口量 が増加しないためであると考えられる.オリフィス開口量 
に関する微粒子の運動状態の確認，流量特性を含めた最適 な駆動条件の確認, 連続的な流量制御の実現は今後の課題 としたい

\section{参 考 文 献}

1）高岩昌弘, 則次俊郎, 佐々木大輔：空気式パラレルマ ニピュレータを用いた手首リハビリテーション，日本 フルードパワーシステム学会論文集, Vol. 43, No. 3, p. 39-46 (2012)

2 ) N. Saga, N. Saito, J. Nagase : Ankle Rehabilitation Device to Prevent Contracture Using a Pneumatic Balloon Actuator, Int. J. of Automation Technology Vol. 5 No. 4 , p. 538-543 (2011)

3 ）秋山悠基, 眞田一志 : 動作感応形パワーアシスト椅子 に関する研究，日本フルードパワーシステム学会論文 集，Vol. 41, No. 6, p. 107-114（2010）

4）安達和紀，横島真人，樋高裕也，中村太郎：軸方向繊 維強化型人工筋肉を用いた小腸検査用多段式蠕動運動 型ロボットの開発，日本フルードパワーシステム学会 論文集，Vol. 43, No. 3, p. 77-84（2012）

5 ）齋藤直樹，佐藤隆智，小笠原隆倫，佐藤俊之：空気圧 ラバーレス人工筋の開発，日本フルードパワーシステ 厶学会論文集，Vol. 43, No. 3, p. 77-84（2012）

6 ) 加藤友規, 大野学, 東知明, 只野耕太郎, 川嶋健嗣, 香川利春 : ゴムベローズを用いた高減衰空気圧ゴム人 工筋の提案と特性解析, 日本フルードパワーシステム 学会論文集, Vol. 42, No. 6, p. 114-119 (2011)

7 ) S. Kurumaya, H, Nabae G. Endo K. Suzumori : Design of Thin McKibben Muscle and Multifilament Sensors and Actuators A : Physical, Structure Volume 261, 1, p. 6674 (2017)

$8 ＼mathrm{~ 赤 木 徹 也 ， 堂 田 周 治 郎 ， 趙 菲 菲 ， 藤 川 敬 広 ： 柔 軟 空 気 ~}$ 圧シリンダを用いた伸縮・湾曲機構の試作と組込みコ ントローラによる姿勢制御日本フルードパワーシステ 厶学会論文集，Vol. 43, No. 3, p. 55-61（2012）

9) Y. Nishioka, M. Uesu, H. Tsuboi, S. Kawamura : Proposal of an Extremely Lightweight Soft Actuator using Plastic Films with a Pleated Structure, 19th International Conference on Mechatronics and Machine Vision in Practice, p. 474-479 (2012)
10) D. Hirooka, K. Suzumori, T. Kanda : Flow control valve for pneumatic actuators using particle excitation by PZT vibrator, Sensors and Actuators A155, p. 285-289 (2009)

11) D. Hirooka, K. Suzumori, T. Kanda : Design and Evaluation of Orifice Arrangement for Particle-Excitaion Flow Control Valve, Sensors and Actuators A171 p. 283291 (2011)

12) D. Hirooka, T. Yamaguchi, N. Furushiro, K. Suzumori, T. Kanda : Particle-Excitation Flow-Control Valve using Piezo Vibration-Improvement for a High Flow Rate and Research on Controllability, 電気学会論文誌E（センサ・ マイクロマシン部門誌)，Vol. 137, No. 1, p. 32-37 (2017)

13）廣岡大祐, 山口智害, 古城直道, 鈴森康一, 神田岳文: 微粒子励振型流量制御弁を用いた空気圧シリンダの速 度制御，日本フルードパワーシステム学会論文集, Vol. 46, No. 2, p. 7-13 (2015)

14) D. Hirooka, T. Yamaguchi, N. Furushiro, K. Suzumori, T. Kanda : Optimization of Orifice Position in Particleexciation Valve for Proportional Flow Control, ROBOMECH Journal, Vol. 4, 25, p. 1-11 (2017)

15）浮田貴宏, 鈴森康一, 難波江裕之, 神田岳文, 大藤翔 輝：微粒子励振型流量制御弁による油圧制御，日本フ ルードパワーシステム学会論文集，Vol. 47，No. 6, p. 1-8 (2016)

16) T. Akagi, S. Dohta, and S. Katayama : Development of Small-sized Flexible Control Valve Using Vibration Motor, Proc.7th JFPS Int. Symposium on Fluid Power, TOYAMA, p. 2-25, (2008)

17) K. P. Fritz, V. Mayer, T. Steffens, H. Kück : Swiching Valve with Isolated Impact Actruator, 12th International Conference on New Actuators, p. 242-245, (2010)

18) S. Dohta, T. Akagi, W. Kobayashi, S. Shimooka : Improvement of a Pneumatic Control Valve with SelfHolding Function, Materials Science and Engineering 249012002 p. 1-8 (2017)

19）浮田貴宏, 鈴森康一, 難波江裕之, 神田岳文：流路に 直交方向の加振を利用した油圧微粒子励振型制御弁の 試作と評価，日本フルードパワーシステ ム学会論文集， Vol. 49, No. 1， p. 10-17 (2018) 